ORIGINALS ( 5 )

\title{
酸化スズ系尓スセンサにおける アルコールガスの無害化
}

\author{
山添显・武藤 行弘・清山 哲郎 \\ 九州大学総合理工学研究科材料開発工学専政 $\bar{\top} 816$ 福岡県春日市春日公園 6 丁目 1 番地 \\ (1984 年 3 月 30 日 受理)
}

\section{Tin Oxide Gas Sensor Insensitive to Ethanol Gas}

\author{
Noboru YAMAZOE, Yukihiro MUTO, and Tetsuro SEIYAMA \\ Department of Materials Science and Technology, Graduate School \\ of Engineering Sciences, Kyushu University \\ 6-1 Kasugakoen, Kasuga-shi, Fukuoka, 816
}

(Received March 30, 1984)

\begin{abstract}
Works of conventional tin oxide gas sensors are often disturbed by a contact with ethanol vapor. In order to remove such a disturbance, it was tried to insensitize the sensor to ethanol by use of oxidation catalysts. Of the twelve different catalysts tested, alumina supported $\mathrm{Pt}$ catalyst $(\mathrm{Pt}(1 \%) /$ $\mathrm{Al}_{2} \mathrm{O}_{3}$ ) was found to be the most effective for total oxidation of ethanol vapor; ethanol was completely oxidized above ca. $200^{\circ} \mathrm{C}$ under the experimental conditions. The effects of $\mathrm{Pt}(1 \%) / \mathrm{Al}_{2} \mathrm{O}_{3}$ catalyst in the actual sensing performance were examined by using three types of sensor elements. As a result, the best data were obtained with the coated element which was prepared by coating the conventional sensor element (base element) with $\mathrm{Pt}(1 \%) / \mathrm{Al}_{2} \mathrm{O}_{3}$ catalyst. The sensitivity of the base element to ethanol vapor was higher than those to $\mathrm{CH}_{4}$ and $\mathrm{C}_{3} \mathrm{H}_{8}$ below $400^{\circ} \mathrm{C}$ and was still significant at $500^{\circ} \mathrm{C}$, The coated element, however, was almost insensitive to ethanol vapor in the temperature range $300 \sim 500^{\circ} \mathrm{C}$, while it was as sensitive to $\mathrm{CH}_{4}$ and $\mathrm{C}_{3} \mathrm{H}_{8}$ as the base element. It was also confirmed that the rate of sensor response was little affected by the catalyst coating.
\end{abstract}

\section{1. 緒言}

$\mathrm{SnO}_{2}$ 系ガスセンサは家庭用ガス漏れ檠報器などに用

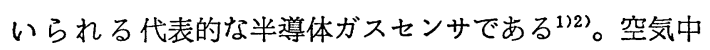
に漏出したプロパンやメタンなどの可然性ガスを高感度 で検知することができ，また経斉性・長期安定性などに あ優れているため広く普及しつつある。てのセンサは, 可然性ガスが $\mathrm{SnO}_{2}$ 表面の吸着酸素あるいは表面酸素と 反応するととによって素子抵抗が減少する，いわゆる表 面制御型センサ ‘゙ある。そのため, 吸着力の強いガス や反応性の高いガスの妨害を受けやすい。一般家庭の場 合台所で発生するアルコールガスが高いガス感度をもつ ために, センサがこれに感応して誤って鳘報を発すると いういわゆる誤動作の原因になりやすく，その様なアル コールによる妨害のないセンサの開発が望まれている。 その方法としてシリカゲルなどの吸着剤を用いてエタノ 一ルガスを吸着除去する方法や半導体素子を酸化触媒で
コーティングしてエタノールガスを燃焼除去する試みが 一部なされているといわれるが，それらの詳細や有用性 については全く公表されていない。エタノールは一般に 検知対象ガスであるプロパンやメタンに比べ, 高い反応 性をむつので酸化触媒を用いてエタノールを選択的に酸 化除去する方法が有望であると期待される。本研究では 各種酸化触媒のエタノール酸化能を調べるとともに, 最 も活性の高い触媒を用いた $\mathrm{SnO}_{2}$ 系センサにおけるアル コールガスの妨害の除去能について検討した。

\section{2. 実験方法}

\section{1 触媒の調製および活性試験}

エタノールの接触酸化に用いた 12 種の触媒は次の様 にして調製した。単独酸化物の $\mathrm{CuO}, \mathrm{NiO}, \mathrm{MnO}_{2}, \mathrm{Co}_{3} \mathrm{O}_{4}$ はそれぞれの硝酸塩水溶液に炭酸アンモニウム水溶液を 加えて得られる沈殿物を $100^{\circ} \mathrm{C}$ で乾燥後, 空気中 $600^{\circ} \mathrm{C}$ で 10 時間焼成して得た。以下他の触媒についても特に 
ことわらない限り燒成条件は $600^{\circ} \mathrm{C}, 10$ 時間（空気中）

である。 $\mathrm{SnO}_{2}$ は金属スズに過剩の濃硝酸を加えて生成 した $\beta$-スズ酸の沈殿をろ過し純水で十分に洗浄したの ち, 空気中室温で乾燥後焼成して得た4)。また $\mathrm{Cr}_{2} \mathrm{O}_{3}$ は 市販品 (石津製薬) を焼成し用いた。 $\gamma-\mathrm{Al}_{2} \mathrm{O}_{3}$ はアルミ ニウムイソプロポキシドを熱水 $\left(95 \sim 98^{\circ} \mathrm{C}\right)$ 中で加水分 解しろ過して $100^{\circ} \mathrm{C}$ で乾燥後, 単独酸化物として用いる 場合には上記条件で焼成し，担持触媒の担体に用いる場 合には $500^{\circ} \mathrm{C}$ で 5 時間焼成して得た。

アルミナ担持触媒は, 上記の $\gamma-\mathrm{Al}_{2} \mathrm{O}_{3}$ を担体として含 浸法により得た。すなわち $\mathrm{Pd}$ および $\mathrm{Pt}$ の担持では塩 化物水溶液および塩化白金酸水溶液を, また $\mathrm{Cu}$ と $\mathrm{Cr}$ の場合には硝酸塩水溶液を含浸した。乾燥後前者につい ては水素流通下 $300^{\circ} \mathrm{C}, 3$ 時間還元処理を加えたのち, 後者についてはそのまま $600^{\circ} \mathrm{C}, 10$ 時間焼成し触媒とし た。以下担持触媒を $\mathrm{Pd}(1 \%) / \mathrm{Al}_{2} \mathrm{O}_{3}$ などと記す。（）内 の数字は担持量 (重量\%) を示す。 $\mathrm{SnO}_{2}$ への $\mathrm{Pd} や \mathrm{Pt}$ の添加は，アルミナ担持触媒の場合と同様 $\mathrm{SnO}_{2} k \mathrm{Pd}$ の塩化物水溶液や塩化白金酸水溶液を含漫し，還元し焼 成して得た。乙の場合得られるあのは, 本質的に担持触 媒であるがセンサ材料の慣例に従いててでは $\mathrm{SnO}_{2}-\mathrm{Pd}$ (0.5\%) などと表わすととにする。

エタノールの接触酸化は常圧固定床流通反応装置を用 いて, 所定温度の触媒層へ原料として空気希釈した約 1

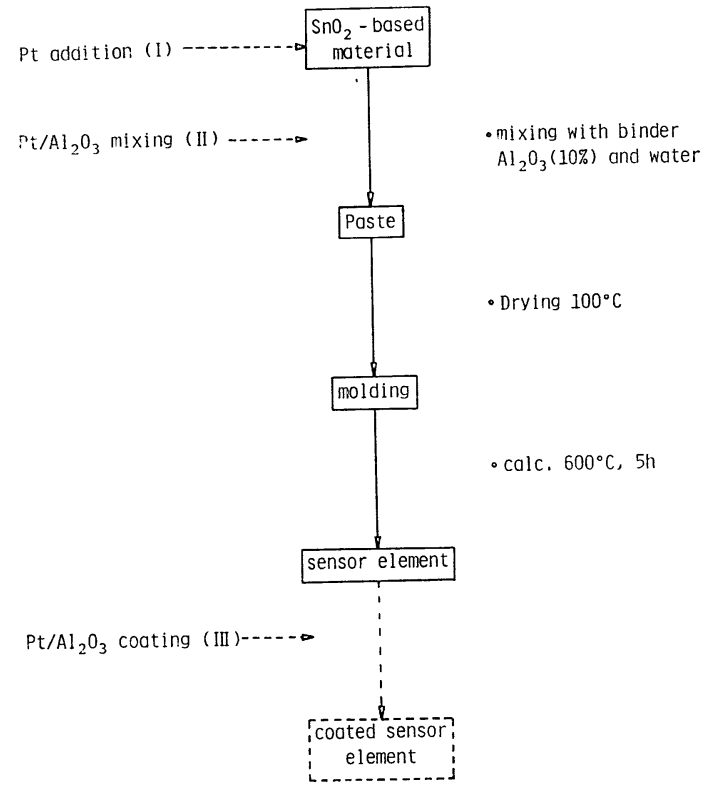

Fig. 1 Preparation of $\mathrm{SnO}_{2}$-based sensor elements. Full arrows indicate procedures for a base element $\left(\mathrm{SnO}_{2}-\mathrm{Pd}\right)$, while dotted arrows indicates those for three modified elements containing $\mathrm{Pt}$ catalysts.

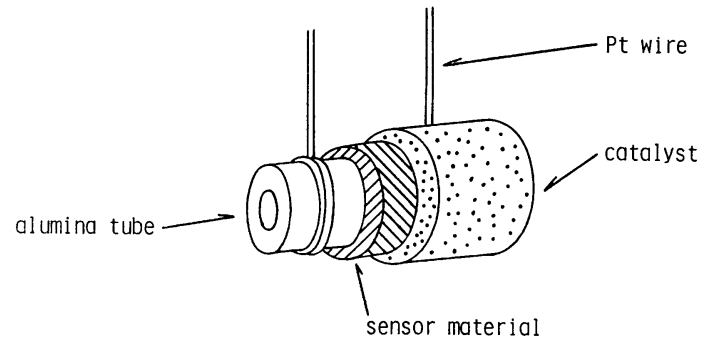

Fig. 2 Sensor element with a catalyst coating.

\%のエタノールを供給して行った。接触時間 (W/F) は すべて $1 \mathrm{~g} \cdot \mathrm{s} \cdot \mathrm{cm}^{-3}$ とした。分析はガスクロで行った。

\section{2 センサ素子の作製}

センサ素子として用いた塗布焼結素子は $\mathbb{F i g} .1$ 亿示 す手順で作製した。図中，実線の矢印および枠で示した 工程は，Pt 触媒を含まないベース素子の作製法を示す。 前節で調製した $\mathrm{SnO}_{2}-\mathrm{Pd}(0.5 \%)$ 粉末にバインダーとし ての $\gamma-\mathrm{Al}_{2} \mathrm{O}_{3}(10 \%)$ および水を加えて混合しペーストに した。他方アルミナ絶縁管（外径 $1.2 \mathrm{~mm}$, 長さ $10 \mathrm{~mm}$ ) の両端に電極として $\mathrm{Pt}$ 線条 $(0.3 \mathrm{~mm} \phi)$ を巻き付けた 構造の基体を作製した ${ }^{5)}$ 。この基体の上に上記ペースト

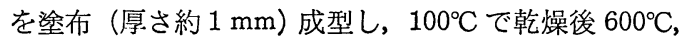
5 時間燒成して, 焼結した。この素子を以後ベース素子 之呼ぶ。

アルコールガスの無害化に対する $\mathrm{Pt}$ 触媒添加の有効 性は添加法が異なる次の3つの素子で検討した。Fig. 1 中破線の矢印で各素子の作製工程を示した。

- 素子 I (共添加素子) : ベース素子に用いる $\mathrm{SnO}_{2}-\mathrm{Pd}$ (0.5\%) 粉末のかわりに $\mathrm{PdCl}_{2}$ および $\mathrm{H}_{2} \mathrm{PtCl}_{6}$ の混 合水溶液を $\mathrm{SnO}_{2}$ 亿含浸し, $\mathrm{SnO}_{2}-\mathrm{Pd}(0.5 \%)$ の場合 之同じ手順で得た $\mathrm{SnO}_{2}-\mathrm{Pd}(0.5 \%)-\mathrm{Pt}(1 \%)$ 粉末を用 い, あとはベース素子と同じ工程で作製した素子であ る。

・素子II（触媒混合素子）：ベース素子作製手順中アル ミナバインダーを同重量の $\mathrm{Pt}(1 \%) / \mathrm{Al}_{2} \mathrm{O}_{3}$ 亿置きかえ たあのである。

・素子III（コーティング素子）:ベース素子表面に, 純 水を加えてペース状にした $\mathrm{Pt}(1 \%) / \mathrm{Al}_{2} \mathrm{O}_{3}$ を塗布して コーティングし， $100^{\circ} \mathrm{C}$ 乾燥後 $600^{\circ} \mathrm{C}, 5$ 時間焼成し た素子である。(Fig. 2 参照) コーティング層の厚さ は約 $0.5 \mathrm{~mm}$ とした。

\section{3. 結果および考察}

\section{1 エタノールの接触酸化}

Fig. 3 にメタン, プロパン, エタノールの完全酸化 反応の自由エネルギー変化を示す。縦軸には酸素 $1 \mathrm{~g}$ 原 


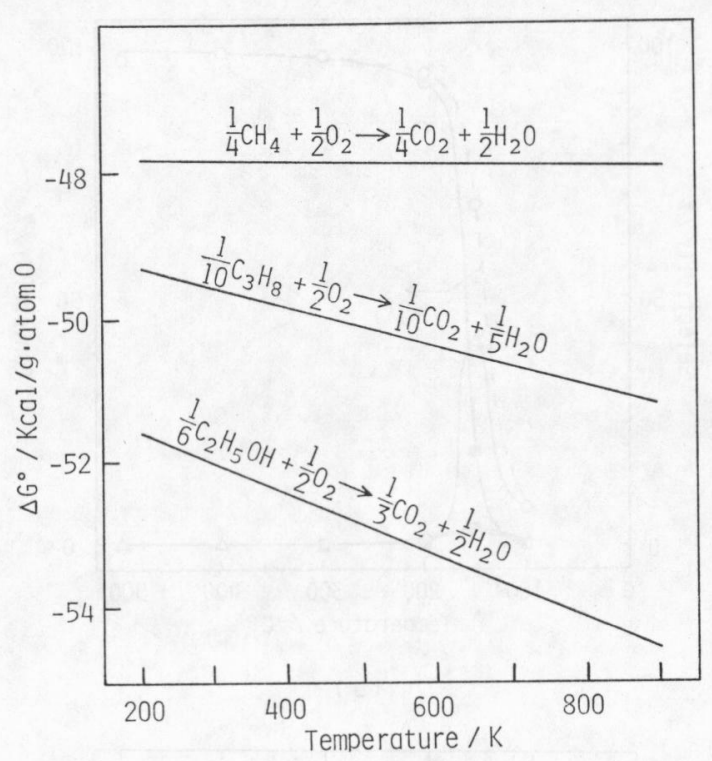

Fig. 3 Temperature dependence of $\Delta G^{\circ}$ for combustion of $\mathrm{CH}_{4}, \mathrm{C}_{3} \mathrm{H}_{8}$ and $\mathrm{C}_{2} \mathrm{H}_{5} \mathrm{OH}$.

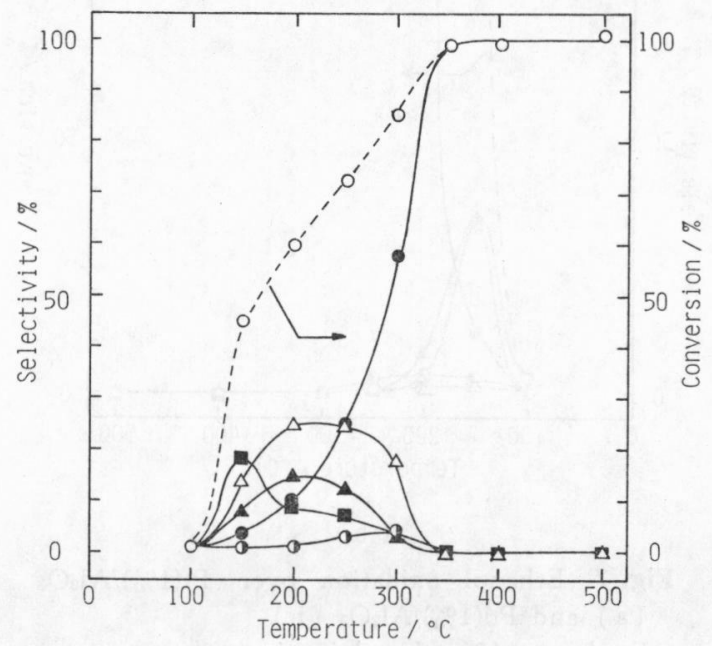

Fig. 4 Oxidation of ethanol on $\mathrm{SnO}_{2}-\mathrm{Pd}(0.5 \%)$. Feed gas : $1 \%$ ethanol in air.

$-\mathrm{CO}_{2},-\mathrm{CH}_{4},-\triangle-\mathrm{CH}_{3} \mathrm{CHO}$
$-\mathrm{CH}_{3} \mathrm{COOH},-\mathrm{CH}_{3} \mathrm{COOC}_{2} \mathrm{H}_{5}$

子当たりの值をとっている。メタンの反応性は温度が変 化してあほとんど変わらないのに比べ, プロパン, エタ ノールの反応性は温度が高くなると大きくなり，特にエ タノールの温度依存性は大きく温度上昇に伴う反応性の 増大が非常に大きい。この様に検知対象ガスとエタノー ルの反応性には大きな差があることからエタノールを選 択的に酸化除去する可能性があることが示唆されよう。 ところで $\mathrm{SnO}_{2}$ 系ガスセンサには，通常 $\mathrm{Pd}$ が増感剤

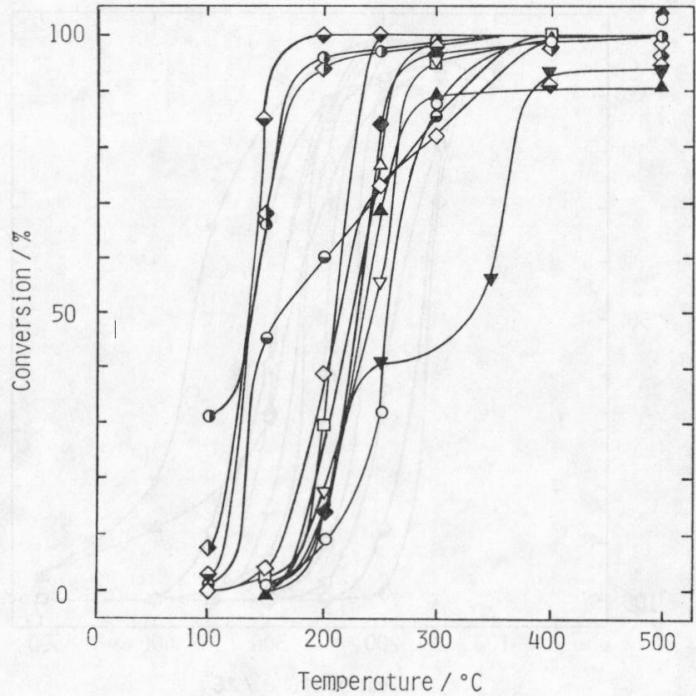

Fig. 5 Ethanol conversion vs. Temperature over various catalysts.

Feed gas : $1 \%$ ethanol in air
$-\triangle-\mathrm{CO}_{3} \mathrm{O}_{4}$
$-\nabla-\mathrm{MnO}_{2}$
$-\mathbf{A}-\mathrm{CuO}$
$-\nabla-\mathrm{Cr}_{2} \mathrm{O}_{3}$
$-\square-\mathrm{NiO}$
$-4 \% \mathrm{Cu}-2 \% \mathrm{Cr} / \mathrm{Al}_{2} \mathrm{O}_{3}$
$-1 \% \mathrm{Pd} / \mathrm{Al}_{2} \mathrm{O}_{3}$
$-\diamond-\mathrm{Al}_{2} \mathrm{O}_{3}$
- $-\mathrm{SnO}_{2}+\mathrm{Pt}(0.5 \%)$
$-\mathrm{O}-\mathrm{SnO}_{2}$
$-\mathrm{SnO}_{2}+\mathrm{Pd}(0.5 \%)$

として少量添加されている6)。乙の様な $\mathrm{Pd}$ 添加系の素 子でエタノールの酸化がどの様に起こるかを知るため に，まず $\mathrm{SnO}_{2}-\mathrm{Pd}(0.5 \%)$ を触媒として行った反応例を Fig. 4 に示す。エタノールは $100^{\circ} \mathrm{C}$ 付近から反応を開 始するが，約 $250^{\circ} \mathrm{C}$ まではアセトアルデヒドや酢酸，酢 酸エチルなどへの部分酸化が主であり， $\mathrm{CO}_{2}$ への完全 酸化は $350^{\circ} \mathrm{C}$ 以上になってはじめて選択率 $100 \%$ で進む ことがわかる。これら部分酸化生成物あすべてセンサに 対する感度が高く妨害作用も強いので, エタノール無害 化のためには単にエタノールを他へ転化するだけでなく これらの部分酸化生成物もまた除去することが要求され る。

Fig. 5 は 12 種の触媒について, エタノール酸化活性 をエタノール転化率で比較したあのである。転化率が 90\%になる温度で活性を比較すると，

$\mathrm{Pd}(1 \%) / \mathrm{Al}_{2} \mathrm{O}_{3}>\mathrm{SnO}_{2}-\mathrm{Pt}(0.5 \%)>\mathrm{Pt}(1 \%) / \mathrm{Al}_{2} \mathrm{O}_{3}>\mathrm{NiO}$ $>\mathrm{Co}_{3} \mathrm{O}_{4}>\mathrm{Cu}(4 \%)-\mathrm{Cr}(2 \%) / \mathrm{Al}_{2} \mathrm{O}_{3}>\mathrm{MnO}_{2}>\mathrm{CuO}$

$>\mathrm{SnO}_{2}>\mathrm{SnO}_{2}-\mathrm{Pd}(0.5 \%)>\mathrm{Al}_{2} \mathrm{O}_{3}>\mathrm{Cr}_{2} \mathrm{O}_{3}$

の順である。しかし，この序列は前述した様にエタノ一 ル無害化の有効性の序列とは必ずしも一致しない。そこ で，エタノールおよびセンサ感度が高い部分酸化生成物 であるアルデヒド，カルボン酸，ケトン，エステルを妨 害ガスとして合計し，これらの気相からの除去効率 $(S)$ を比較した。結果を Fig. 6 に示す。この図から妨害ガ 

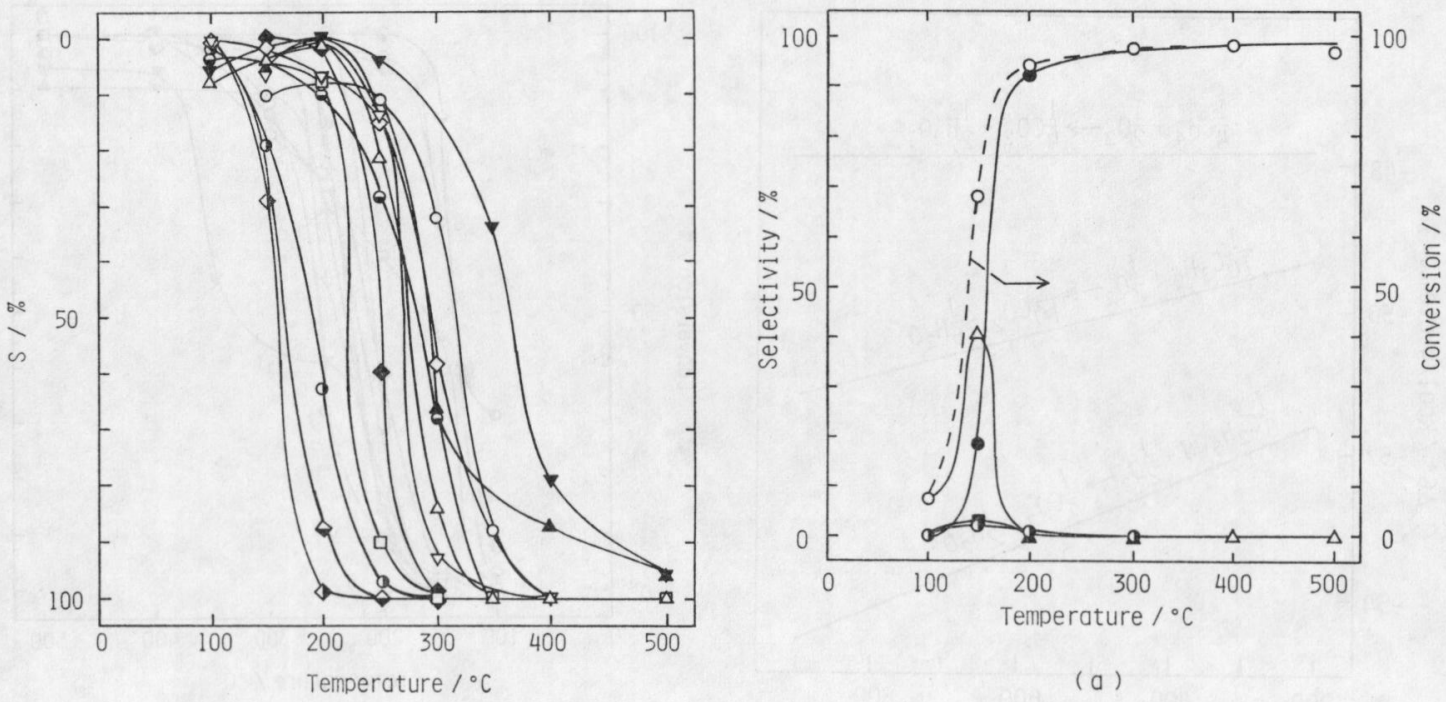

(a)

Fig. 6 Degree of removal of ethanol and strongly interfering partial oxidation products over various catalysts.

Feed gas : $1 \%$ ethanol in air

The marks stand for the same catalysts as shown in Fig. 5 .

Table 1 Effectiveness of the examined catalysts for removal of ethanol and interfering products.

$\mathrm{Pt} / \mathrm{Al}_{2} \mathrm{O}_{3}\left(182^{\circ} \mathrm{C}\right)>\mathrm{Pd} / \mathrm{Al}_{2} \mathrm{O}_{3}\left(205^{\circ} \mathrm{C}\right)>\mathrm{SnO}_{2}+\mathrm{Pt}\left(231^{\circ} \mathrm{C}\right)$ $>\mathrm{NiO} \quad\left(250^{\circ} \mathrm{C}\right)>4 \% \mathrm{Cu}-2 \% \mathrm{Cr} / \mathrm{Al}_{2} \mathrm{O}_{3} \quad\left(275^{\circ} \mathrm{C}\right)$ $>\mathrm{MnO}_{2}\left(293^{\circ} \mathrm{C}\right)>\mathrm{Co}_{3} \mathrm{O}_{4}\left(310^{\circ} \mathrm{C}\right)>\mathrm{SnO}_{2}+\mathrm{Pd}\left(317^{\circ} \mathrm{C}\right)$ $>\mathrm{SnO}_{2}\left(356^{\circ} \mathrm{C}\right)>\mathrm{Al}_{2} \mathrm{O}_{3} \quad\left(357^{\circ} \mathrm{C}\right)>\quad \mathrm{CuO} \quad\left(430^{\circ} \mathrm{C}\right)$ $>\mathrm{Cr}_{2} \mathrm{O}_{3}\left(456^{\circ} \mathrm{C}\right)>$

ス除去率が $90 \%$ になる温度および各触媒の有効性の序 列は Table 1 の様に求められる。一般に酸化物より貴金 属触媒が有効で, 特に $\mathrm{Pt}(1 \%) / \mathrm{Al}_{2} \mathrm{O}_{3}$ が最も有効である ととがわかった。Fig. 7 にエタノール酸化活性が高い $\mathrm{Pt}(1 \%) / \mathrm{Al}_{2} \mathrm{O}_{3}$ ¿ $\mathrm{Pd}(1 \%) / \mathrm{Al}_{2} \mathrm{O}_{3}$ の反応例を示す。 $\mathrm{Pt}$ (1\%) $/ \mathrm{Al}_{2} \mathrm{O}_{3}$ では約 $100^{\circ} \mathrm{C}$ からアセトアルデヒドが生成 し, $200^{\circ} \mathrm{C}$ 以上ではその逐次酸化により完全に $\mathrm{CO}_{2}$ へ 転化する。 $\mathrm{Pd}(1 \%) / \mathrm{Al}_{2} \mathrm{O}_{3}$ では反応開始温度は $\mathrm{Pt}(1 \%) /$ $\mathrm{Al}_{2} \mathrm{O}_{3}$ よりわずかに高いだけであるが，アセトアルデヒ ドの逐次酸化による酢酸の生成や酢酸とエタノールとの 反応による酢酸エチルの生成が起こり, 完全に $\mathrm{CO}_{2}$ へ 酸化されるには約 $300^{\circ} \mathrm{C}$ の高温を必要とする。

\section{2 エタノールガス無害化に対する白金触媒の効果}

前節で述べた様に接触酸化能から言えば，アルコール 無害化には Pt 触媒が最む有効であると判断される。そ こで Pt 触媒を用いてセンサ素子におけるアルコール無 害化を検討した。その場合素子への $\mathrm{Pt}$ 触媒の添加法に

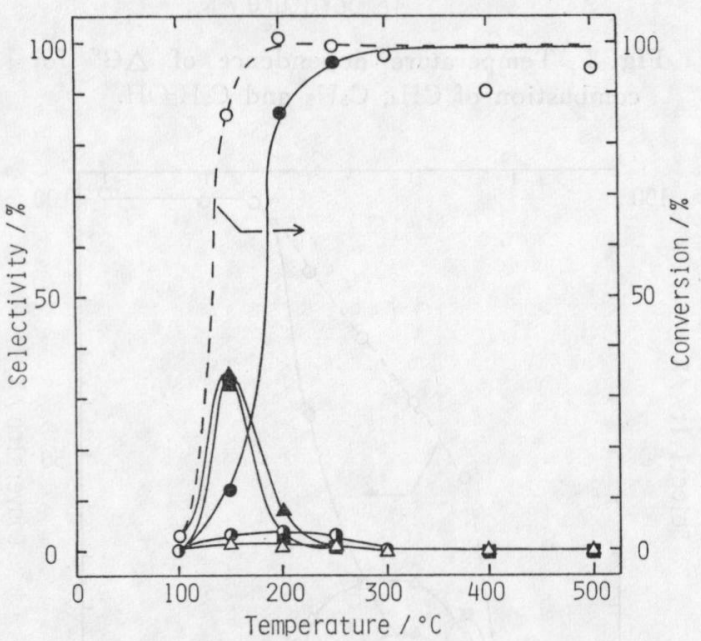

(b)

Fig. 7 Ethanol oxidation over $\mathrm{Pt}(1 \%) / \mathrm{Al}_{2} \mathrm{O}_{3}$ (a) and $\mathrm{Pd}(1 \%) / \mathrm{Al}_{2} \mathrm{O}_{3}$ (b)

Feed gas : $1 \%$ ethanol in air

$$
\text { - } \mathrm{CH}_{4},-\mathrm{CO}_{2},-\triangle-\mathrm{CH}_{3} \mathrm{CHO}
$$

よって有効性が異なると思われるので, 2.2 節で述べた 3 種類の添加法を用いた。Fig. 8 に Pt 触媒を添加して いない素子 (ベース素子 $\mathrm{SnO}_{2}-\mathrm{Pd}(0.5 \%)$ ), 共添加素子 $\left(\mathrm{SnO}_{2}-\mathrm{Pd}(0.5 \%)-\mathrm{Pt}(1 \%)\right), \mathrm{Pt}(1 \%) / \mathrm{Al}_{2} \mathrm{O}_{3}$ をべース素子 に塗布したコーティング素子および, $\mathrm{Pt}(1 \%) / \mathrm{Al}_{2} \mathrm{O}_{3}$ を 機械混合した触媒混合素子 $\left(\mathrm{SnO}_{2}-\mathrm{Pd}(0.5 \%)+\mathrm{Pt}(1 \%) /\right.$ $\left.\mathrm{Al}_{2} \mathrm{O}_{3}\right)$ のメタン, プロパンおよびエタノールの検出特性 を温度をかえて测定した結果を示ず。ベース素子では,

* 図中ガス感度は空気中での素子抵抗 Ra と被検ガス中で の素子抵抗 Rs との比 Ra/Rs を表わす。 


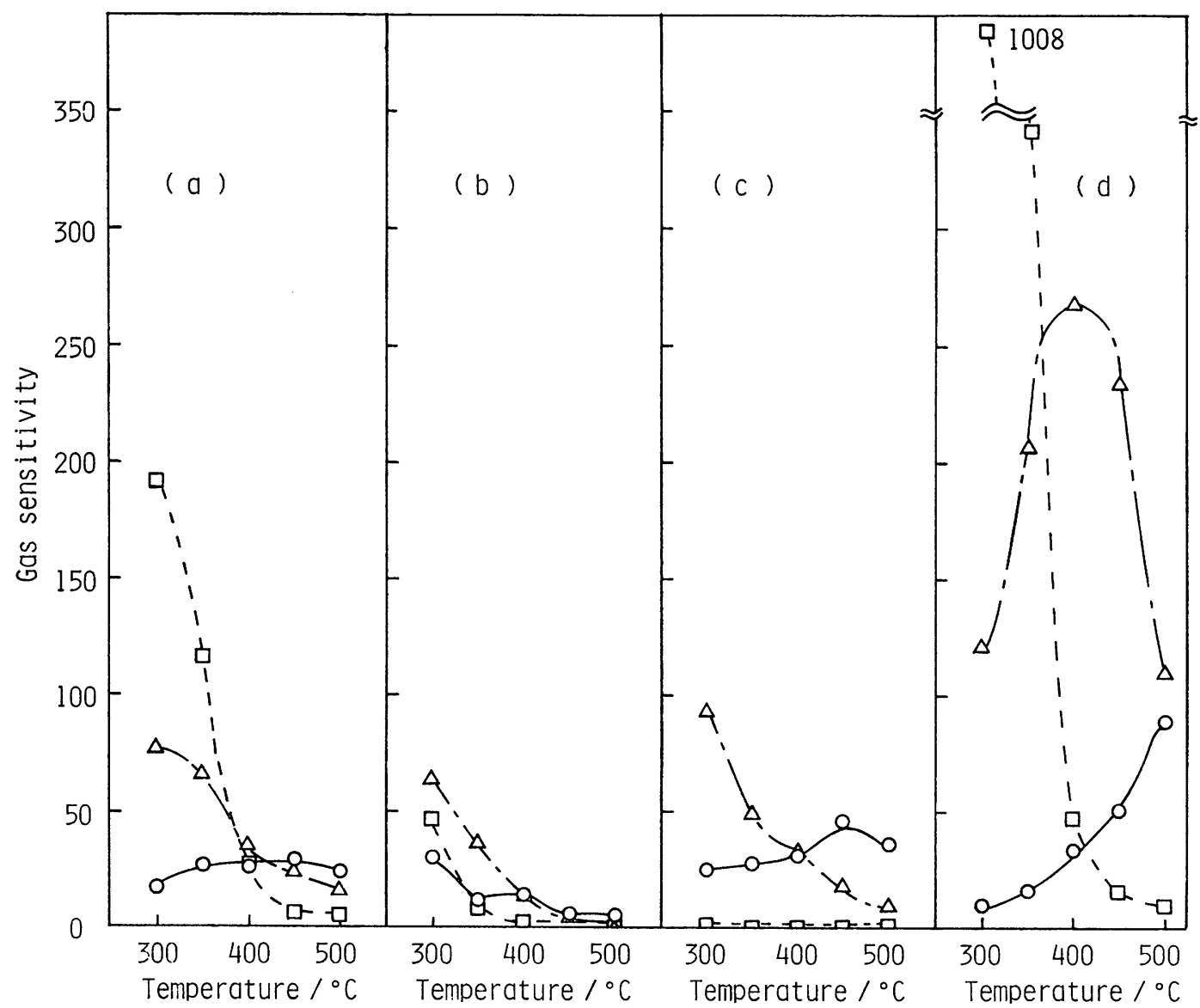

Fig. 8 Gas sensitivity vs. temperature for (a ) base element $\left(\mathrm{SnO}_{2}-\mathrm{Pd}(0.5 \%)\right.$ ), (b) $\mathrm{Pt}$-coadded element $\left(\mathrm{SnO}_{2}-\mathrm{Pd}(0.1 \%)-\mathrm{Pt}(1 \%)\right)$, (c) $\mathrm{Pt} / \mathrm{Al}_{2} \mathrm{O}_{3}$-coated element, (d) $\mathrm{Pt}_{2} / \mathrm{Al}_{2} \mathrm{O}_{3}$-mixed element. $-\mathrm{O}-0.5 \% \mathrm{CH}_{4}$ in air $-\triangle-0.2 \% \mathrm{C}_{3} \mathrm{H}_{8}$ in air $-\square-0.1 \% \mathrm{C}_{2} \mathrm{H}_{5} \mathrm{OH}$ in air

エタノールのガス感度は低温度で高く，400 C でメタン

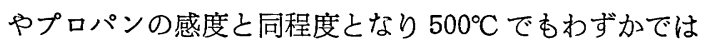
あるが感度を有する。従ってての素子を約 $400^{\circ} \mathrm{C}$ 以下の 温度で作動させて，メタンやプロパンを測定しようとす れば, エタノールは強い妨害作用を示すととになる。共添 加素子では, エタノールの感度は相当低下し, $400^{\circ} \mathrm{C}$ 以上 ではほとんど無くなるが,メタンやプロパンの感度す減 少するので, それほど有効とは言えない。これに対しコー ティング素子では，エタノールの感度のみを $300^{\circ} \mathrm{C}$ 以上 でほとんどゼロにする一方，メタンやプロパンの感度に は悪影響を与えない。この点で, コーティング素子はエタ ノールの無害化に極めて有効であると言える。共添加素

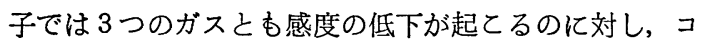
ーティング素子では, エタノールの感度のみが選択的に 低下するのは, 後者では, コーティング層でエタノール 酸化が優先的に起こるのに対して, 前者では $\mathrm{SnO}_{2}$ に担 持された貴金属上で 3 種のガスとも酸化消費され $\mathrm{SnO}_{2}$
表面に到達するガス濃度が低下するためと推定される が，詳細は現在のところ不明である。ベース素子材料粉 体 $\left(\mathrm{SnO}_{2}-\mathrm{Pd}(0.5 \%)\right)$ ¿ $\mathrm{Pt}(1 \%) / \mathrm{Al}_{2} \mathrm{O}_{3}$ 粉末とを混合し 成型して得た触媒混合素子では, 無添加素子に比べてい ずれのガスに対してむガス感度増大 (増感効果) が観測 され，またガス感度一温度特性も異ったものが得られた。 すなわちメタンの感度は温度ととあに単調に増大し， $500^{\circ} \mathrm{C}$ で約 100 に達し，プロパンのそれは $400^{\circ} \mathrm{C}$ で極大 值 270 を示した。一方, エタノールの感度は $300^{\circ} \mathrm{C}$ で極 大となり極大值は約 1000 にも達するととがわかった。 この様にこの素子では顕著な増感効果はあるが，エタノ ール無害化には有効でないと言える。なお増感効果の発 現については定かでないが, $\mathrm{Pt}(1 \%) / \mathrm{Al}_{2} \mathrm{O}_{3}$ 粉末を混合 したととによる素子の微細構造の影響が大きいのではな いかと考えられる。

エタノールの無害化の有効性を比較するには, エタノ ールと検知対象ガスであるメタン, プロパンとの感度比 


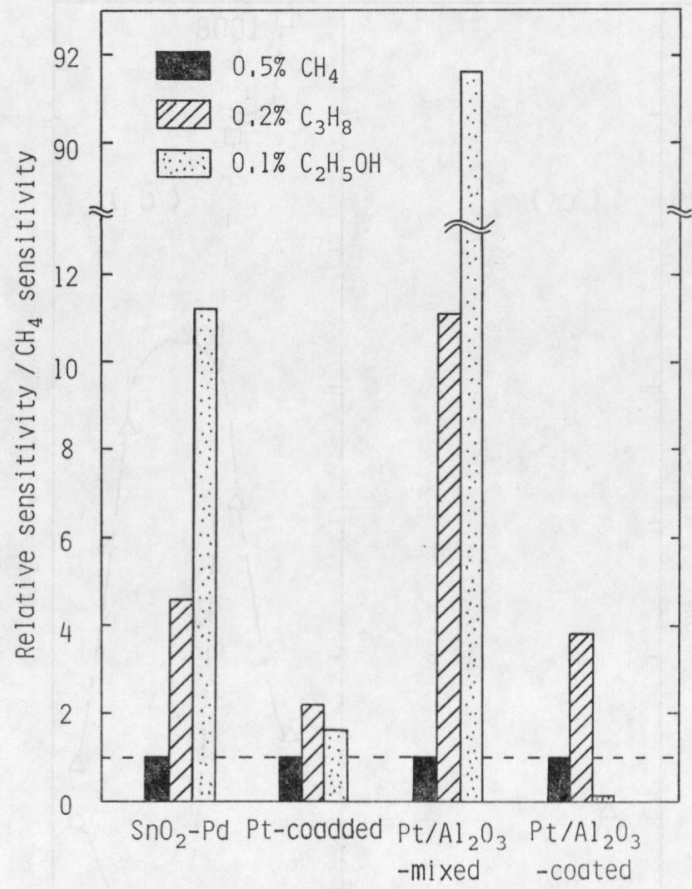

Fig. 9 Gas sensitivities relative to $\mathrm{CH}_{4}$ for $\left(\mathrm{SnO}_{2}-\mathrm{Pd}(0.5 \%)\right)$-based sensors. $\left(300^{\circ} \mathrm{C}\right)$

が問題になる。そとでメタンの感度を基準として $300^{\circ} \mathrm{C}$ における相対感度を比較した結果を Fig. 9 に示す。べ ース素子および触媒混合素子ではエタノールの相対感度 がメタンやプロパンに比べて非常に高く, エタノールの 妨害を受けることがわかる。共添加素子ではエタノール の相対感度は大きく減少するが，依然メタン感度よりむ 大きく完全に除去するととができず，またプロパンの相 対感度も減少する。一方, コーティング素子ではメタン やプロパンの相対感度はほとんど変化させるととなく, エタノールの相対感度のみを有効に低下させるととがわ かる。コーティング素子では触媒コーティングがエタ， ールを選択的に酸化無害化する一種のフィルターの役割 を果たすと言えよう。

\section{3 コーティング素子の応答速度}

エタノール無害化に最も効果的なコーティング素子の 実用化を考慮する場合，コーティング層による応答速度 への悪影響が懸念されるが，この点は問題がないととを 確認した。Fig.10はメタンあるいはエタノールを含むガ スを流通あるいは遮断したときのベース素子 $\left(\mathrm{SnO}_{2}-\mathrm{Pd}\right.$ $(0.5 \%))$ とコーティング素子の応答を示す。通常応答速 度の目安として全出力の $90 \%$ に達するまでの時間( $90 \%$ 応答時間 $\mathrm{T}_{90 \%}$ ）が用いられる。メタンへの応答は触媒 層のあるなしにかかわらず T $90 \%$ が約 30 "で非常に速い 応答を示した。プロパンへの応答も触媒層のあるなしに
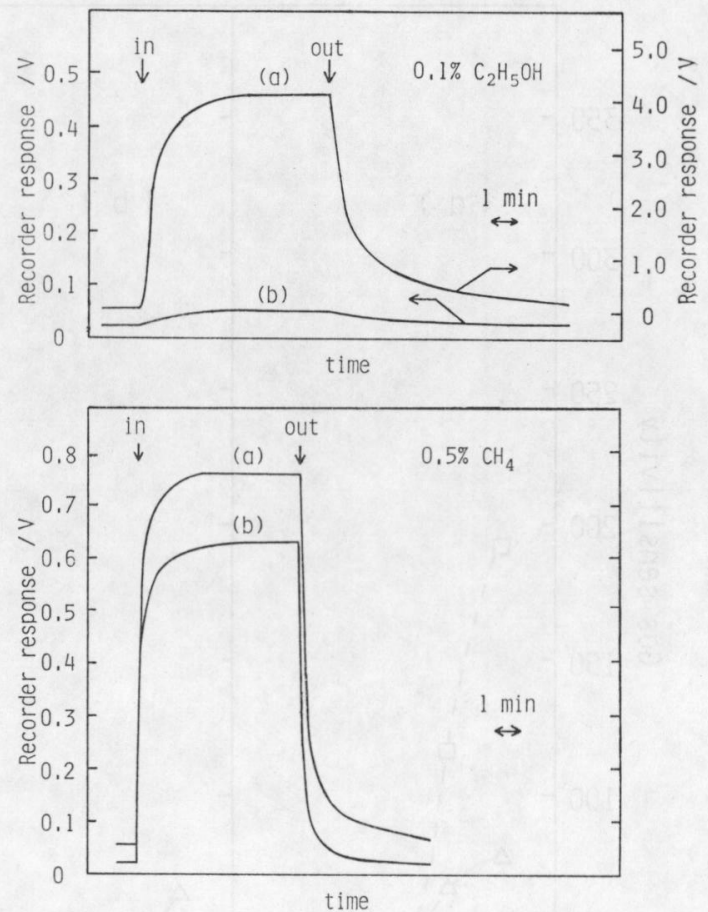

Fig. 10 Effects of catalyst coating on sensor response to $0.5 \% \mathrm{CH}_{4}($ lower $)$ and $0.1 \% \mathrm{C}_{2} \mathrm{H}_{5}$ $\mathrm{OH}($ upper).

(a) base element $\left(\mathrm{SnO}_{2}-\mathrm{Pd}(0.5 \%)\right)$

(b) $\mathrm{Pt}(1 \%) / \mathrm{Al}_{2} \mathrm{O}_{3}$-coated element

かかわらず T90\% が 50" であった。一方エタノールへの 応答は T90\% が約 $2^{\prime} 30^{\prime \prime}$ と比較的遅い, コーティング素 子ではいくぶん応答速度が遅くなる傾向にあるが，この 場合は触媒層によって感度そのものが極度に低下するの で実際上問題とはならない。以上のように検知対象ガス であるメタン, プロパンの応答速度は十分大きく, コー ティング層の影響もほとんどないととから実用上まった く支障がないと考えられる。

\section{4. 結 論}

$\mathrm{SnO}_{2}$ 系センサでメタンやプロパンを測定する際のエ タノールガスの妨害を除去するために, 酸化触媒によっ てエタノールを選択的に酸化除去する方法を種々検討 し, 次の結論を得た。

（1）エタノールの接触酸化能は用いた 12 種の酸化触 媒のうち, Pt P $\mathrm{Pd}$ を $\gamma$ アルミナに担持したものが 最高の活性を示した。エタノールの無害化において は，酸化生成物むまたガス感度の低いむのでなければ ならず，その点からは Pt 系が最も優れている。Pt $(1 \%) / \mathrm{Al}_{2} \mathrm{O}_{3}$ の場合, 接触酸化の反応条件下では $200^{\circ} \mathrm{C}$ 以上で殆んど完全にアルコールを無害な物質へと転換 
できる。

（2）アルコール無害化に対する Pt 触媒添加の有効性 は, ベース素子 $\left(\mathrm{SnO}_{2}-\mathrm{Pd}(0.5 \%)\right)$ の表面に $\mathrm{Pt}(1 \%) /$ $\mathrm{Al}_{2} \mathrm{O}_{3}$ 粉末を塗布コーティングした素子 (コーティン グ素子）によって確認された。すなわち，ベース素子 の場合エタノールは $400^{\circ} \mathrm{C}$ 以下ではメタンやプロパン

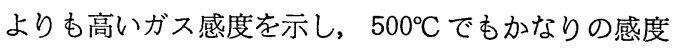
を示すのに対してコーティング素子では $300^{\circ} \mathrm{C}$ 以上で のエタノール感度を殆んど完全になくするてとができ た。酸化反応結果から推察するとコーティング技術を 改良するととにより $200^{\circ} \mathrm{C}$ 以上のエタノール感度をな くすることができると期待される。

（3）コーティング素子のメタンやプロパンへの応答速 度は非コーティング素子と同程度であり, コーティン
グ層の存在は応答速度に悪影響を与えないととがわか った。

\section{文献}

1) T. Seiyama, S. Kagawa: Anal. Chem. 38 (1966) 1069.

2) 田口尚義：特公昭 45-38200 (出願昭 37).

3) 清山哲郎, 山添 开: 化学々工業 34 (1981) 10.

4) N. Yamazoe, J. Fuchigami, M. Kishikawa, T. Seiyama : Surf. Sci. 86 (1979) 335.

5) 五百蔵弘典：電気化学 50 (1982) 99.

6) 清山哲郎, 二田穂皘, 江良筆子, 山添 开: 電気 化学 40 (1972) 224. 